\title{
Reproductive cycle and the occurrence of abnormal larvae in Brancbiostoma lanceolatum at Helgoland
}

\author{
W. A. M. Courtney \\ Department of Zoology, Westfield-College, London University; \\ London, England
}

KURZFASSUNG: Der Fortpflanzungszyklus von Branchiostoma lanceolatum und das Auftreten von abnormen Larven bei Helgoland. Untersuchungen an der bei Helgoland auftretenden Population des Lanzettierchens Branchiostoma lanceolatum haben gezeigt, daß bei mehr als $50 \%$ der Individuen die Gonadenentwicklung zwei Jahre nach dem Ansetzen der Larven beginnt. Geschlechstreife Individuen laichen im Juni oder in der ersten Hälfte des Juli. Die planktonische Lebensphase der Larven dauert ca. 21/2 Monate. Bei 4,5\% der im Jahr 1963 gefangenen Larven traten verschiedene Abnormitäten auf; es konnte jedoch nicht geklärt werden, $o b$ diese durch die niedrigen Temperaturen während des strengen Winters 1962/63 hervorgerufen worden waren.

\section{INTRODUCTION}

Branchiostoma lanceolatum (PALlas) extends from the north-east coast of Africa through the Mediterranean Sea to the North Sea. Although this species is active over a lower range of temperatures than the sub-tropical and tropical forms (PARKER, 1908; WEBB, 1958; CourtNeY \& WEBB, 1964) the winter temperatures of the North Sea exert lethal and sub-lethal effects upon the population at Helgoland (COURTNEY, 1974). There is no growth in the winter months when the temperature is less than $10^{\circ} \mathrm{C}$ whereas growth is continuous in the Mediterranean populations and the oxygen uptake profiles show that the animal is adapted to temperatures of $10-25^{\circ} \mathrm{C}$ (COURTNEY \& NeWELL, 1965).

\section{MATERIAL AND METHOD}

Adults were collected in Van Veen samples taken at a depth of $20 \mathrm{~m}$ in sandy gravel $5 \mathrm{~km}$ north east of the island Helgoland at 6 week intervals throughout the year. Larvae were obtained during the daily plankton hauls of the Meeresstation Helgoland and during the spawning period additional nettings were made over the Branchiostoma grounds at a variety of depths. 


\section{RESULTS}

\section{Gonad development}

The embryonic gonadial tissue is attached to the median side of the gonadial cavities which lie in the atrium at the junction of the skeletal muscle with the atrial floor. Maturation had not begun in animals which were almost 2 years old in August, although 3 months later $56 \%$ of this annual group had developing gonads (Table 1).

\section{Table 1}

Percentage of 2-group animals with developing gonads

\begin{tabular}{|lccc|}
\hline Date & Age (months) & $\begin{array}{c}\text { \% animals } \\
\text { with gonads }\end{array}$ & $\mathrm{n}$ \\
\hline November 1962 & 26 & 56 & 80 \\
February 1963 & 28 & 58 & 36 \\
April 1963 & 31 & 60 & 81 \\
June 1963 & 33 & 63 & 96 \\
July 1963 & 34 & 59 & 70 \\
August 1962 & 35 & 57 & 57 \\
November 1962 & 38 & 100 & \\
\hline
\end{tabular}

The number of animals with developing gonads remained more or less constant during the third year of life until the following autumn when all of the animals, which had settled 3 years earlier, were developing gonads.

\section{Maturation and spawning}

The gonads of immature animals increased in size very slightly during the winter. The maximum size of gonad in a $30 \mathrm{~mm}$ animal before the third winter was $0.013 \mathrm{~mm}^{3}$, if treated as a cylinder, and $0.015 \mathrm{~mm}^{3}$ in animals of the same length in the following April. There is rapid enlargement subsequently, so that in June the volume of the gonad is $0.3 \mathrm{~mm}^{3}$ in an animal of length $33 \mathrm{~mm}$. The gonads enlarge in subsequent years until there is a long tube of gonadial material interrupted by the segmental gonadial membranes.

The sperm mother cells, whose characteristic arrangement was described by BOVERI (1892), are attached to the membrane in the region of a blood vessel which passes along the atrial surface of the gonads. Spawning had not begun on 7.6.1963 at Helgoland and all of the adults had spawned by 15.7.1963. The male gonopore (Fig. 1) protrudes from the surface of the spent gonad (Fig. 2). Each ovary has 2 openings, of unequal size, lying close to the blood vessel in the gonadial envelope (Fig. 3). Between successive spawnings the gonopores close and the thickened epithelium, described as 'scars' by LIEBER (1903) and ZarNIK (1904), is present in both mature and immature animals. 
Muscles continuous with the muscle of the inner surface of the epipleure pass between each gonad as a thin sheet (Fig. 4). Contraction of this muscle would assist the discharge of gametes into the atrial cavity whence they are flushed out of the animal either by the feeding/respiratory current maintained by the lateral cilia of the gill bars or by the movements of the atrial floor.

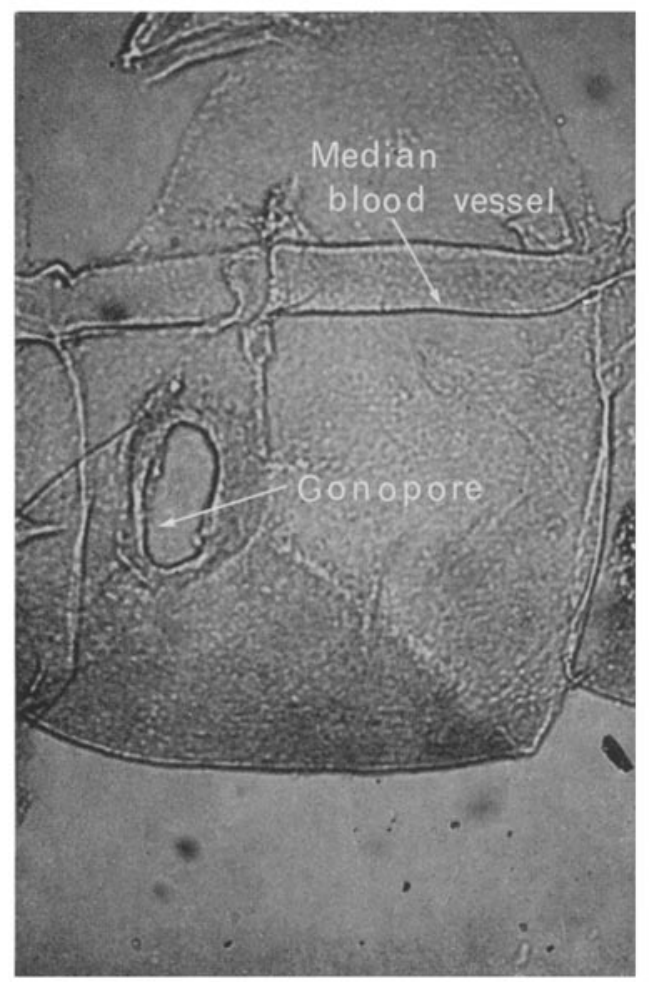

Fig. 1: Brancbiostoma lanceolatum. Gonadial membrane of a spent testis with the gonopore lying beneath the median blood vessel

\section{Planktonic larvae}

The relationship between length and number of gill pouches of the larvae taken between mid-August and early September 1963 is shown in Figure 5. The maximum number of gill pouches was 16 and later larvae exhibited absorption of gill pouches during metamorphosis (WILLEY, 1894). However, these larvae were small compared with the larvae taken earlier which had probably already settled.

Two abnormal larvae were taken on 24.8. and on 6.9. These were small $(1.3-2.7 \mathrm{~mm})$ and differed from each other in structural detail. Both nerve cord and notochord were present although in one the notochord did not extend in front of the nerve cord so that there was an eyespot at the anterior end of the body (Fig. 5). The 


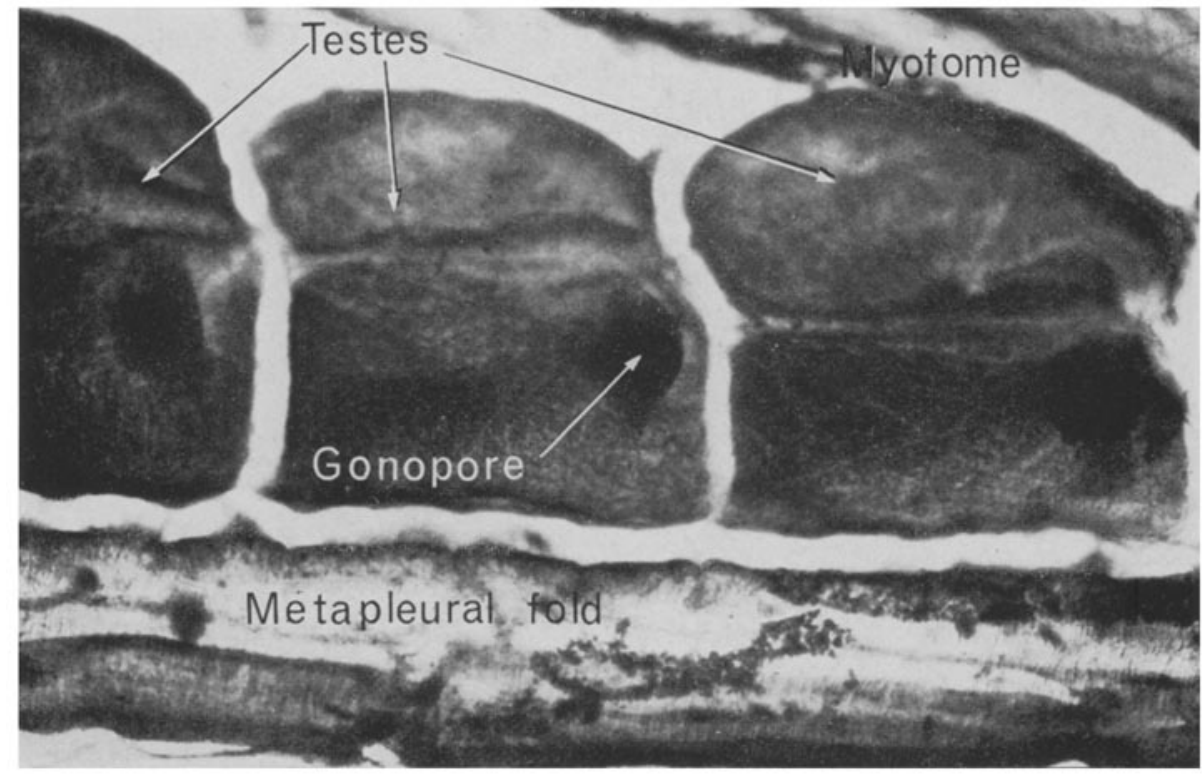

Fig, 2: Branchiostoma lanceolatum. Gonopore scar tissues protruding from the median surface of the testes

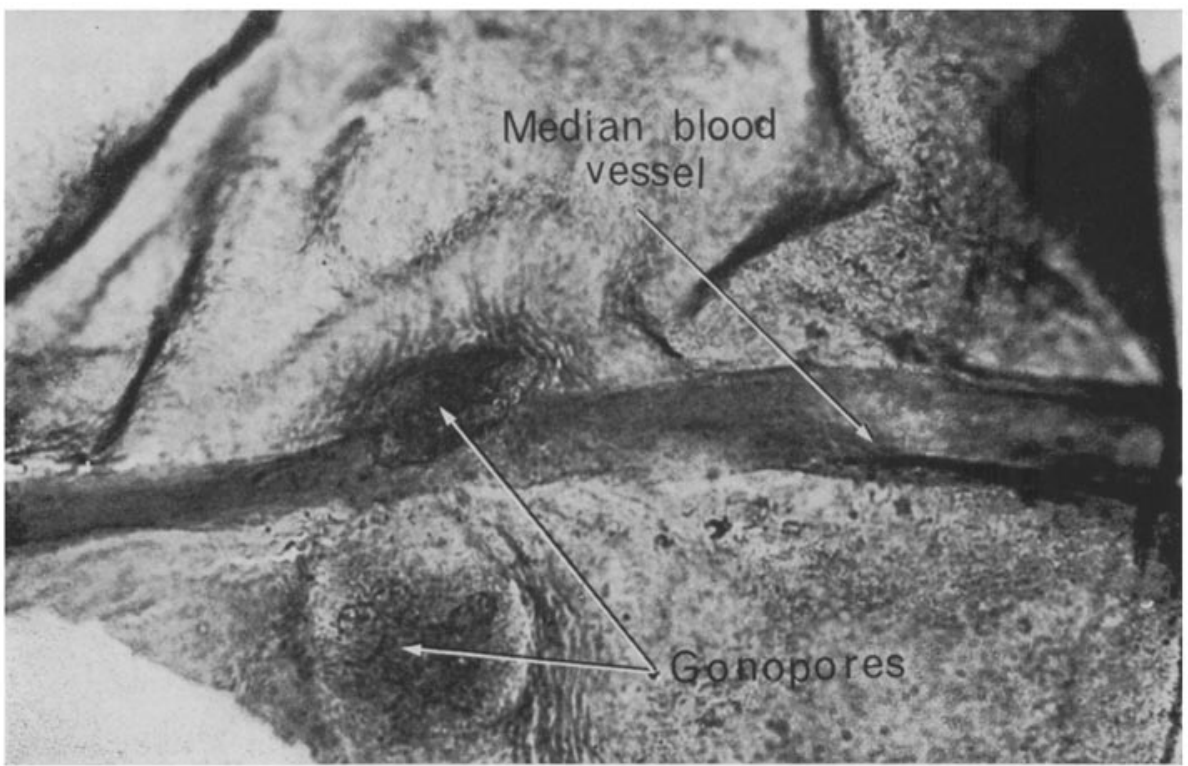

Fig. 3: Branchiostoma lanceolatum. Median membrane of the ovary of a mature animal showing scar tissue of the two gonopores, one dorsal and the other ventral to the median blood vessel 


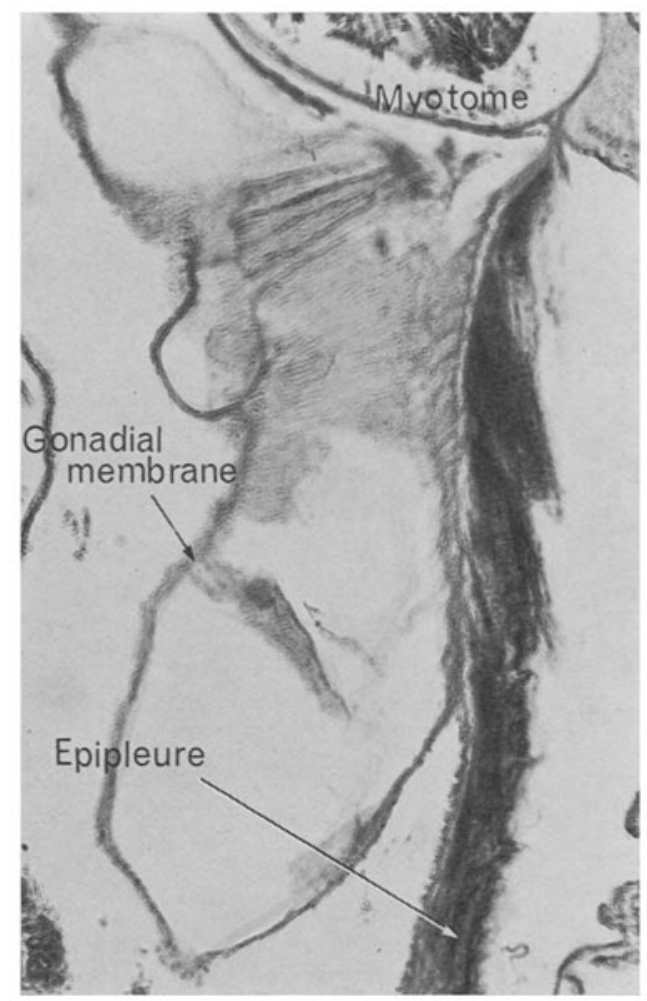

Fig. 4: Branchiostoma lanceolatum. Muscle, in the gonadial membrane between adjoining gonads, which is continuous with the muscle of the inner surface of the epipleure

gill pouches were ill-defined in all of the larvae and the mouth was absent in one of them together with the ilio-colonic ring. The gut and the nerve cord appeared to be continuous around the posterior end of the body in one specimen and a second row of gill pouches was developing in another. Further signs of metamorphosis were absent.

The gross feature distinguishing the abnormal larvae from normal larvae was the body thickness. The notochord was thicker and not tapered at either end when com-

Table 2

Size/frequency of newly settled individuals $/ 2 \mathrm{~mm}^{2}$

\begin{tabular}{|crrrrrr|}
\hline Length $(\mathrm{mm})$ & 4 & 5 & 6 & 7 & 8 & 9 \\
\hline 5.11 .1962 & 1 & 6 & 23 & 20 & 13 & 1 \\
2.9 .1963 & 1 & 29 & 6 & - & - & - \\
4.11 .1963 & - & - & 3 & 7 & 2 & - \\
20.9 .1965 & 13 & 50 & 41 & 5 & - & - \\
\hline
\end{tabular}




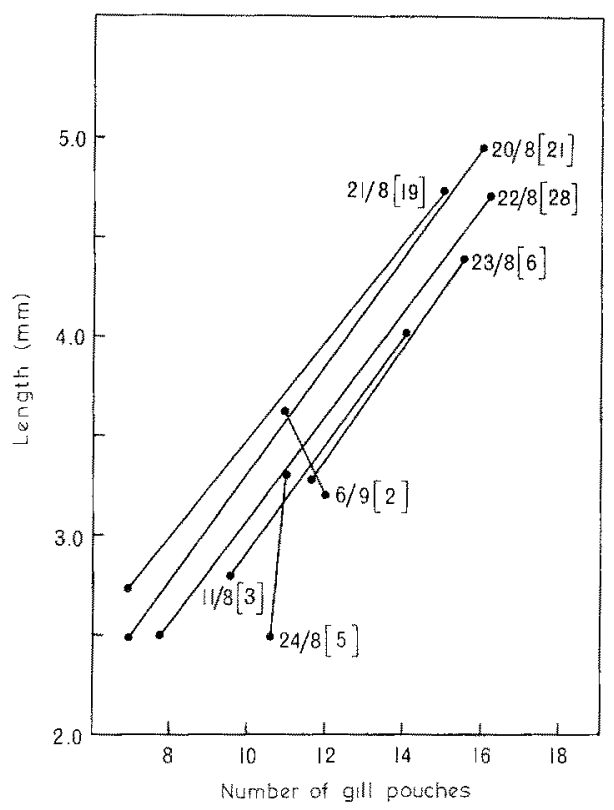

Fig. 5: Brancbiostoma lanceolatum. Relationship between length and number of gill pouches of larvae taken between mid-August and early September 1963

pared with a normal larva of the same length (Fig. 6). The notochord is, relatively, thicker in younger larvae (length $0.6 \mathrm{~mm}$ ) normally.

No larvae were taken in vertical plankton hauls above the Branchiostoma grounds nor in the Van Veen grabs.

\section{Settlement}

Four days before the last larvae were taken in the plankton, newly metamorphosed animals had settled on the adult grounds in 1963. Table 2 shows that in 1963 and 1965 most of the newly settled individuals were $5-6 \mathrm{~mm}$ in length. The wider range of size in November $1962(4-9 \mathrm{~mm})$ may indicate prolonged settlement in that year.

\section{DISCUSSION}

The gonads of Branchiostoma are derived segmentally from the ventral myocoelic epithelium and prior to spawning they appear as conspicuous white masses in the atrial region of the body. HAGMEIER \&. HiNRICHS (1931) found that all of the ripe Branchiostoma taken into the laboratory at Helgoland, together with all of the animals in the field, had spawned by June 17th. Spawning occurred at about the same time, or perhaps a little later, in 1963 and is synchronous with the period of spawning at Naples (Bone, 1957). 

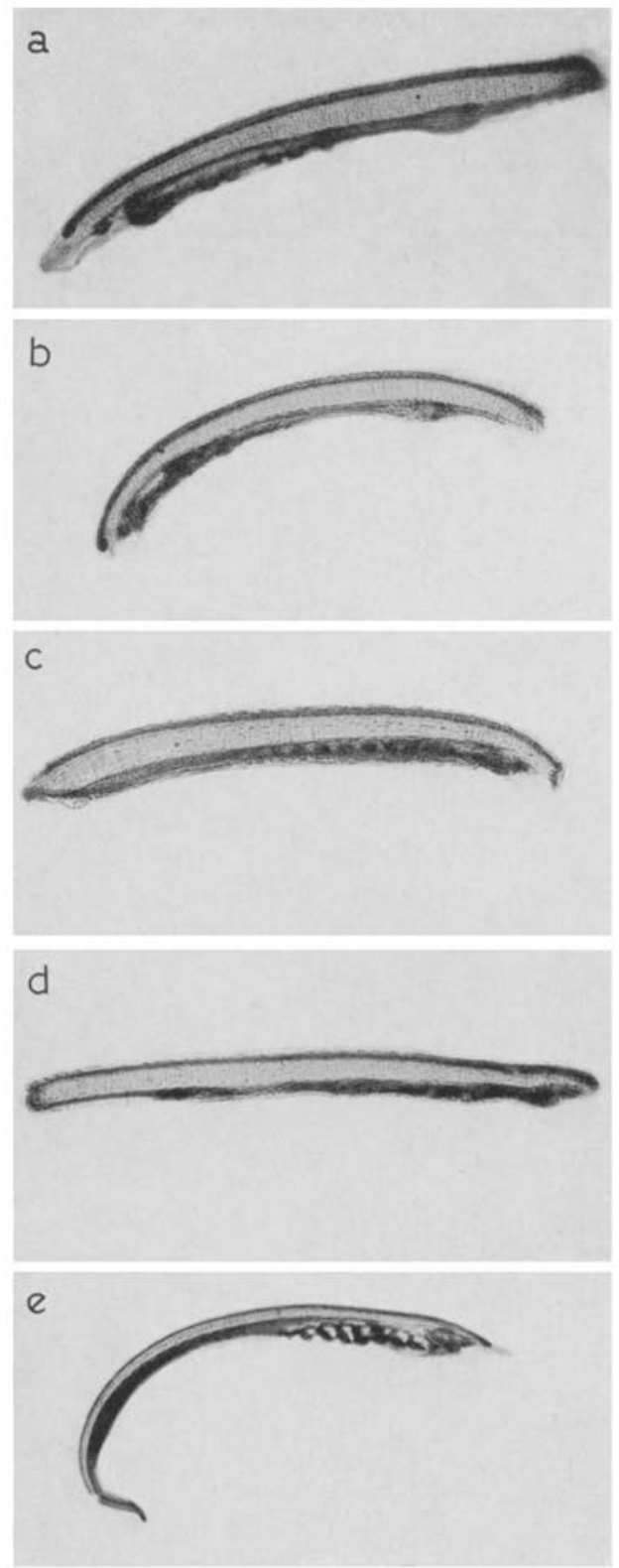

Fig. 6: Branchiostoma lanceolatum. Four abnormal larvae $(a-d)$ and one normal larva $(e)$ taken in 1963. Lengths: $a=1.3 \mathrm{~mm} ; b=1.5 \mathrm{~mm} ; c=1.7 \mathrm{~mm} ; d=2.7 \mathrm{~mm} ; e=2.7 \mathrm{~mm}$ 
Larvae were taken in the surface plankton at Helgoland during late August and early September, although the small size of the newly settled individuals in November 1962 and the large catches of larvae by HARTMAN \& JoHn (1971) over the Dogger Bank in mid-September shows that, in some years at least, larvae may be found in the plankton over a 3 month period. Probably, recruitment of $B$. lanceolatum in the North Sea occurs between populations (WEBB, 1974). Nevertheless, the larval life of this species is unlikely to be shorter than the 75 days larval life of $B$. nigeriense described by WEBB (1958).

The larvae of B. lanceolatum are found to depths of $55 \mathrm{~m}$ over the Dogger Bank (HARTMANN \& John, 1971) and B. senegalense larvae are found at all depths off the coast of the Spanish Sahara (Gosselck \& KeuHnER, 1973) although, as in the North Sea, no larvae were found in the sediments. $B$. lanceolatum larvae were found in the surface plankton during the day at Helgoland and over the Dogger Bank, though neither CHIN (1941) nor WICKSTEAD \& BONE (1955) could find the larvae of B. belcheri at the surface except at night. WEBB (1974) reviews the feeding behaviour of the larva of this genus together with their transport by currents and the factors rendering a sediment suitable for settlement.

The reproductive cycle of $B$. lanceolatum is temperature dependent and there is no increase in the percentage of immature animals of the Helgoland population developing gonads from one autumn to the next. Sea temperatures are above $15^{\circ}$ whilst the larvae are planktonic and metamorphosing and this species, which extends from the north-east African coast to Bergen in Norway, is a reproductive stenotherm.

Abnormal larvae have not been described previously. It is not known whether these appear annually in the North Sea or whether they were confined to the summer of 1963, in which case, they may be a further factor operating within the Helgoland population (CourTNEY \& WEBB, 1964) as a result of the cold winter of $1962 / 63$.

\section{SUMMARY}

1. At Helgoland (North Sea), $56 \%$ of Brancbiostoma lanceolatum develop gonads in their third year.

2. Spawning occurs annually through sexually dimorphic descrete areas of the gonadial envelope.

3. The planktonic larvae have a maximum number of 16 gill pouches and settle after $21 / 2$ months.

4. Four of the 88 larvae taken at Helgoland in 1963 had a thick notochord and an ill-defined gut. These abnormal larvae differed from each other in structural detail.

Acknowledgements. I wish to thank Professor Dr. O. Kinne for generous facilities and boat time provided at the Biologische Anstalt Helgoland (Meeresstation Helgoland), and Professor Dr. M. GrllbRicht for kindly providing the temperature profiles over the Brancbiostoma grounds. Technical assistance was given by Mr. A. Hol.TMann and Miss C. Earte. 


\section{LITERATURE CITED}

Bone, Q., 1958. The asymmetry of the larval amphioxus. Proc. zool. Soc. Lond. 130, 289-293. BOVERI, 'T., 1892. Über die Bildungsstätte der Geschlechtsdrüsen und die Entstehung der Genitalkammern beim Amphioxus. Anat. Anz, 7, 170-181.

CHIN, T. G., 1941. Studies on the biology of the Amoy amphioxus Branchiostoma belcheri (GRAY). Philipp. J. Sci. 75, 369-424.

Courtney, W. A. M., 1974. The temperature relationships and age-structure of North Sea and Mediterranean populations of Branchiostoma lanceolatum. Symp. zool. Soc. Lond. 36, 213-234.

- \& WEBB, J. E., 1964. The effects of the cold winter of $1962 / 63$ on the Helgoland population of Branchiostoma lanceolatum (PALlas). Helgoländer wiss. Meeresunters. 10, 301-312.

- \& NEWELL, R. C., 1965. Ciliary activity and oxygen uptake in Branchiostoma lanceolatum (PALLAS). J. exp. Biol. 43, 1-12.

Gosselck, F. \& KUEHNER, E., 1973. Investigations on the biology of Brancbiostoma senegalense larvae off the north-west African coast. Mar. Biol. 22, 67-73.

Hagmerer, A. \& Hinrichs, J., 1931. Bemerkungen über die Okologie von Branchiostoma lanceolatum (PALlas) und die Sedimente seines Wohnortes. Senckenberg. biol. 13, 255-267.

Hartman, von J. \& John, H.-C., 1971. Planktische Branchiostoma nordwestlich der Doggerbank (Nordsee). Ber. dt. Wiss. Kommn. Meeresforsch. 22, 80-84.

LIEBER, A., 1903. Uber Bau und Entwicklung der weiblichen Geschlechtsorgane des Amphioxus lanceolatus. Zool. Jber. Neapel 20, 1-39.

Parker, G. H., 1908. The sensory reactions of Amphioxus. Proc. Am. Acad. Arts Sci. 43, $415-455$.

WeBB, J. E., 1958. The ecology of Lagos Lagoon. Part III. The life history of Brancbiostoma nigeriense Wевв. Phil. Trans. R. Soc. (B) 241, 335-353.

- 1974. The distribution of Ampbioxus. Symp. zool. Soc. Lond. 36, 179-212.

- \& Hill, M. B., 1958. The ecology Lagos Lagoon. Part IV. On the reactions of Brancbiostoma nigeriense WeBB to its environment. Phil. Trans. R. Soc. (B) 241, 355-391.

WickstEAD, J. H. \& BONE, Q., 1959. Ecology of acraniate larvae. Nature, Lond. 184, 18491851.

Zarnik, B., 1904. Uber die Geschlechtsorgane von Amphioxus. Zool. Jber. Neapel 21, 1-86.

Author's address: Dr. Williamina A. M. Courtney

Department of Zoology

Westfield College

London NW3 7ST

England 